\title{
Dynamic right ventricular outflow tract obstruction in cardiac surgery
}

André Y. Denault, MD, FRCPC, ${ }^{a}$ Miguel Chaput, MD, ${ }^{\mathrm{b}}$ Pierre Couture, MD, FRCPC, ${ }^{\text {a }}$ Yves Hébert, MD, FRCSC, ${ }^{b}$ François Haddad, MD, FRCPC, ${ }^{c}$ Jean-Claude Tardif, MD, FRCPC ${ }^{c}$

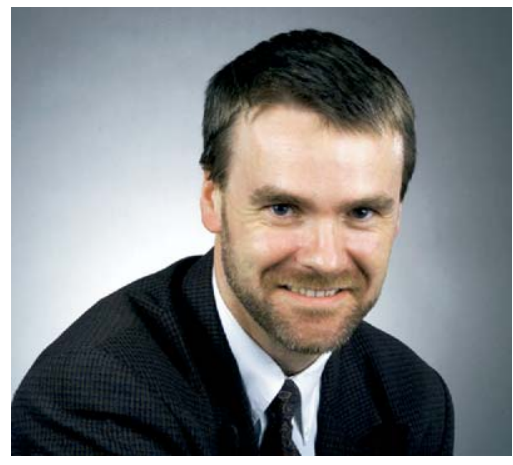

Dr Denault
From the Departments of Anesthesiology, ${ }^{\mathrm{a}}$ Surgery $^{\mathrm{b}}$ and Medicine, ${ }^{\mathrm{c}}$ Montreal Heart Institute and University of Montreal, Montreal, Quebec, Canada.

Supported by the Fonds de la recherche en santé du Québec, the Fondation de l'Institut de Cardiologie de Montréal and the Canadian Institutes of Health Research.

Address for reprints: André Y. Denault, MD, FRCPC, Department of Anesthesiology, Montreal Heart Institute, 5000 Bélanger Street, Montreal, Quebec H1T 1C8, Canada. Tel: (514) 376-3330 ext. 3732; Fax: (514) 376-8784. (E-mail: denault@ videotron.ca)

J Thorac Cardiovasc Surg 2006;132:43-9

$0022-5223 / \$ 32.00$

Copyright $(9) 2006$ by The American Association for Thoracic Surgery

doi:10.1016/j.jtcvs.2006.03.014
Background: Right ventricular outflow tract obstruction can be a cause of hemodynamic instability but it has not been described in non-congenital cardiac surgery.

Methods: The prevalence of right ventricular outflow tract obstruction was retrospectively studied in 670 consecutive patients undergoing cardiac surgery. Significant right ventricular outflow tract obstruction was diagnosed if the right ventricular systolic to pulmonary artery peak gradient was more than $25 \mathrm{~mm} \mathrm{Hg}$. The diagnosis was based on measurement of the right ventricular and pulmonary artery systolic pressure through the paceport and distal opening of the pulmonary artery catheter. To further validate the prevalence and the importance of right ventricular outflow tract obstruction, 130 patients were prospectively studied over a 12-month period.

Results: In the retrospective cohort, 6 patients (1\%) undergoing various types of cardiac surgical procedures were found to have significant dynamic right ventricular outflow tract obstruction with a mean gradient of $31 \pm 4 \mathrm{~mm} \mathrm{Hg}$ (26 to $35 \mathrm{~mm} \mathrm{Hg}$ ). In the prospective study significant dynamic right ventricular outflow tract obstruction was identified in 5 patients (4\%) (average peak: $37 \pm 15 \mathrm{~mm} \mathrm{Hg}$; range: 27 to $60 \mathrm{~mm} \mathrm{Hg}$ ). The typical transesophageal echocardiography finding was end-systolic obliteration of the right ventricular outflow tract. In patients with significant dynamic right ventricular outflow tract obstruction, hemodynamic instability was present in $10 / 11$ patients $(91 \%)$.

Conclusions: Right ventricular outflow tract obstruction is easily diagnosed using the paceport of the pulmonary artery catheter and should be considered as a potential cause of hemodynamic instability especially when transesophageal echocardiography reveals systolic right ventricular cavity obliteration.

$\mathrm{H}$ emodynamic instability after cardiac surgery has various etiologies including ventricular dysfunction, hypovolemia, tamponade, left ventricular outflow tract (LVOT) obstruction and sometimes a combination of these factors. ${ }^{1}$ Right ventricular outflow tract (RVOT) obstruction, which can be due to extrinsic ${ }^{2-4}$ or intrinsic causes, ${ }^{5-7}$ can also result in hemodynamic instability. According to time-honoured hemodynamic criteria, RVOT obstruction is defined as "significant" when the peak right ventricular to pulmonary artery systolic gradient exceeds $25 \mathrm{~mm} \mathrm{Hg} .{ }^{8}$ Furthermore, on transesophageal echocardiography (TEE), significant RVOT obstruction is defined as "fixed" if there is no change in RVOT dimensions during the cardiac cycle with anatomic substrate for obstruction, and as "dynamic" if RVOT dimensions increase appreciably in diastole. Dynamic RVOT obstruction has been observed in hypertrophic cardiomyopathy ${ }^{9}$ and after lung transplantation ${ }^{10,11}$ but it has rarely been described during cardiac surgery. ${ }^{12}$ Over a 3-year period, new-onset significant dynamic RVOT obstruction was seen in 11 patients undergoing cardiac surgery. The diagnosis of RVOT obstruction was made 


\section{Abbreviations and Acronyms}

AVR = aortic valve replacement

$\mathrm{CPB}=$ cardiopulmonary bypass

HTN = hypertension

LVOT $=$ left ventricular outflow tract

$\mathrm{RVOT}=$ right ventricular outflow tract

TEE = transesophageal echocardiography using continuous right ventricular pressure and pulmonary artery pressure monitoring. After having identified and characterized this anomaly in a retrospective study, we hypothesized that this new knowledge integrated in a systemic hemodynamic and echocardiographic assessment would allow determination of a higher but correct incidence of this problem in a prospective study. Our objective was also to better understand the mechanism and risk factors involved in the appearance of RVOT obstruction.

TABLE 1. Retrospective series

\begin{tabular}{|c|c|c|c|c|c|c|c|c|c|c|}
\hline & Age & Sex & Procedure & $\begin{array}{l}\text { Predisposing } \\
\text { factor }\end{array}$ & HTN & PHT & $\begin{array}{c}\text { CPB } \\
\text { duration } \\
\text { (min) }\end{array}$ & DSB & Details & Outcome \\
\hline 1 & 75 & $\mathrm{~m}$ & $\begin{array}{l}\text { Coronary } \\
\text { revascularization } \\
\text { and AVR }\end{array}$ & $\begin{array}{l}\text { Inotropes and } \\
\text { LVH }\end{array}$ & $Y$ & $\mathrm{~N}$ & 147 & $Y$ & $\begin{array}{l}\text { Return on CPB } 3 \text { times, } \\
\text { intra-aortic balloon } \\
\text { pump inserted. } \\
\text { Noradrenaline } 66 \mu \mathrm{g} / \\
\text { min, adrenaline } 4 \mu \mathrm{g} / \\
\text { min, vasopressine } 2 \\
\text { units/hour, nitric oxide } \\
20 \mathrm{ppm} \text {, milrinone } 50 \\
\mu \mathrm{g} / \mathrm{kg} \text { and dopamine } 5 \\
\mu \mathrm{g} / \mathrm{kg} / \text { min. Milrinone } \\
\text { and dopamine were } \\
\text { discontinued once the } \\
\text { diagnosis was made }\end{array}$ & $\begin{array}{l}\text { Develop acute renal failure, } \\
\text { and acute respiratory } \\
\text { distress syndrome, } \\
\text { vasoactive support for } 24 \\
\text { hours, hospitalisation } 20 \\
\text { days }\end{array}$ \\
\hline 2 & 46 & $f$ & $\begin{array}{l}\text { Coronary } \\
\text { revascularization } \\
\text { and aortic } \\
\text { surgery }\end{array}$ & $\begin{array}{l}\text { Inotropes and } \\
\text { LVH }\end{array}$ & $\mathrm{N}$ & $Y$ & 346 & $Y$ & $\begin{array}{l}\text { Noradrenaline } 13 \mu \mathrm{g} / \mathrm{min} \text {, } \\
\text { vasopressin } 2 \text { units } \\
\text { bolus and nitroglycerine } \\
1.3 \mu \mathrm{g} / \mathrm{kg} / \mathrm{min} \text {, inhaled } \\
\text { prostacyclin } 60 \mu \mathrm{g}, \\
\text { milrinone } 50 \mu \mathrm{g} / \mathrm{kg}, \\
\text { methylene blue } 50 \mathrm{mg}\end{array}$ & $\begin{array}{l}\text { Vasoactive support for } 10 \\
\text { hours, hospitalisation } 10 \\
\text { days }\end{array}$ \\
\hline 3 & 58 & $\mathrm{~m}$ & $\begin{array}{l}\text { AVR, MVR, aortic } \\
\text { surgery }\end{array}$ & $\begin{array}{l}\text { Inotropes and } \\
\text { LVH }\end{array}$ & $\mathrm{N}$ & $Y$ & 205 & $Y$ & $\begin{array}{l}\text { Noradrenaline } 2.5 \mu \mathrm{g} / \mathrm{min} \text {, } \\
\text { inhaled prostacyclin } 60 \\
\mu \mathrm{g} \text { and inhaled } \\
\text { milrinone } 5 \mathrm{mg}, \\
\text { nitroglycerine } 0.5 \mu \mathrm{g} / \mathrm{kg} / \\
\text { min }\end{array}$ & $\begin{array}{l}\text { Vasoactive support } 3 \text { hours, } \\
\text { hospitalisation } 8 \text { days }\end{array}$ \\
\hline 4 & 51 & $\mathrm{~m}$ & $\begin{array}{l}\text { AVR, VSD closure, } \\
\text { aortic surgery }\end{array}$ & Inotropes & $\mathrm{N}$ & $Y$ & 129 & $Y$ & $\begin{array}{l}\text { Noradrenaline } 10 \mu \mathrm{g} / \mathrm{min} \text {, } \\
\text { vasopressine } 2 \text { units } \\
\text { bolus, milrinone } 50 \mu \mathrm{g} / \\
\text { kg, methylene blue } 100 \\
\text { mg }\end{array}$ & $\begin{array}{l}\text { Vasoactive support } 3 \text { hours, } \\
\text { ventricular tachycardia } \\
\text { requiring pace- } \\
\text { defibrillator, } \\
\text { hospitalisation } 19 \text { days }\end{array}$ \\
\hline 5 & 62 & $\mathrm{~m}$ & $\begin{array}{l}\text { Septal } \\
\text { myomectomy, } \\
\text { aortic surgery }\end{array}$ & $\begin{array}{l}\text { Septal } \\
\text { hypertrophy }\end{array}$ & $Y$ & $\mathrm{~N}$ & 86 & $Y$ & $\begin{array}{l}\text { Noradrenaline } 12.5 \mu \mathrm{g} / \\
\mathrm{min}, \text { nitroglycerine } 0.7 \\
\mu \mathrm{g} / \mathrm{kg} / \mathrm{min}\end{array}$ & $\begin{array}{l}\text { Vasoactive support } 20 \\
\text { hours, acute renal } \\
\text { failure, hospitalisation } 18 \\
\text { days }\end{array}$ \\
\hline 6 & 68 & $\mathrm{~m}$ & $\begin{array}{l}\text { Coronary } \\
\text { revascularization }\end{array}$ & $\begin{array}{l}\text { Inotropes and } \\
\text { LVH }\end{array}$ & Y & $\mathrm{N}$ & 93 & $Y$ & $\begin{array}{l}\text { Noradrenaline } 7.5 \mu \mathrm{g} / \mathrm{kg} \text {, } \\
\text { nitroglycerine } 0.7 \mu \mathrm{g} / \mathrm{kg} / \\
\text { min, milrinone } 50 \mu \mathrm{g} / \mathrm{kg}\end{array}$ & $\begin{array}{l}\text { Vasoactive support } 2 \text { hours, } \\
\text { hospitalisation } 6 \text { days }\end{array}$ \\
\hline
\end{tabular}

$A V R$, aortic valve replacement; $C P B$, cardiopulmonary bypass; $D S B$, difficult separation from CPB (details in Table 4); f, female; $H T N$, hypertension; $L V H$, left ventricular hypertrophy; $\mathrm{m}$, male; min, minutes; MVR, mitral valve repair; $P H T$, pulmonary hypertension; VSD, ventricular septal defect. 


\section{Methods}

After approval by the Research and Ethics Committees of our institution, the Department of Anesthesia has maintained for quality control purpose, a TEE database since 1999 to store demographic, hemodynamic and echocardiographic data. Informed consent was obtained from all patients for intraoperative use of pulmonary artery catheterization and TEE. Since August 2002, a retrospective analysis of all patients undergoing cardiac surgery was performed. Demographic data included age, gender and the presence of hypertension defined through patient's history and medications. All these patients were monitored by continuous right ventricular pressure waveform analysis through the pulmonary artery catheter paceport (Edwards Lifescience, Irvine, Ca). The paceport opening is located at $19 \mathrm{~cm}$ from the distal end of the catheter. Transducers extension tubing are connected to the distal port and to the paceport of the pulmonary artery catheter. The catheter is advanced until the hemodynamic curve from the paceport changes from an atrial to a ventricular pressure waveform. Then the catheter is maintained in this position throughout the procedure therefore allowing continuous monitoring of right ventricular and pulmonary artery pressure waveforms. In all patients, after the induction of anesthesia, routine hemodynamic waveforms were acquired during insertion of the pulmonary artery catheter. The normal gradient between right ventricular and pulmonary artery systolic pressure is 0 to $3 \mathrm{~mm} \mathrm{Hg}^{13}$ and peak gradients between 3 and $25 \mathrm{~mm} \mathrm{Hg}$ are often considered trivial based on the literature pertaining to chronic RVOT obstruction. In contrast, peak gradients above $25 \mathrm{~mm} \mathrm{Hg}$ are considered significant ${ }^{8}$ and this cut-off value was used in this study. The gradient is calculated as the difference between the peak systolic right ventricular pressure and peak systolic pulmonary artery pressure using the hemodynamic tracing or directly calculated from the monitor. In addition to pulmonary artery catheterization, perioperative TEE monitoring (Philips, Sonos 5500, Andover, Ma) was performed by a cardiac anesthesiologist trained and board-certified in TEE in all patients undergoing cardiac surgery. The echocardiographic exam included the recommended views, ${ }^{14}$ the evaluation of diastolic function $^{15}$ and the interrogation of all four valves by color Doppler. Color Doppler imaging in the mid-oesophageal four-chamber view between 0 to $70^{\circ}$ was used to detect tricuspid regurgitation and continuous-wave Doppler was positioned to obtain the maximum regurgitant jet to measure the peak tricuspid regurgitant velocity. This peak velocity reflects the peak pressure gradient between the right ventricle and right atrium through the Bernouilli equation. $^{16}$

Echocardiographic images suggestive of the abnormal RVOT obstruction were obtained through 2D echocardiography using a inflow-outflow view of the right ventricle or through a deep transgastric view at $40^{\circ}$ as previously described. ${ }^{17}$

Pulmonary hypertension was defined as a preoperative mean pulmonary artery pressure above $25 \mathrm{~mm} \mathrm{Hg}$ obtained during preoperative catheterization or a systolic pulmonary artery pressure above $30 \mathrm{~mm} \mathrm{Hg}^{18}$ measured directly in the operating room. Left ventricular hypertrophy was determined using either electrocardiographic findings ${ }^{19}$ or the following echocardiographic criteria: posterior wall thickness $\geq 12 \mathrm{~mm}$, left ventricular mass above $131 \mathrm{~g} / \mathrm{m}^{2}$ in men or $110 \mathrm{~g} / \mathrm{m}^{2}$ in women. Difficult separation from cardiopulmonary bypass (CPB) was identified as systolic blood

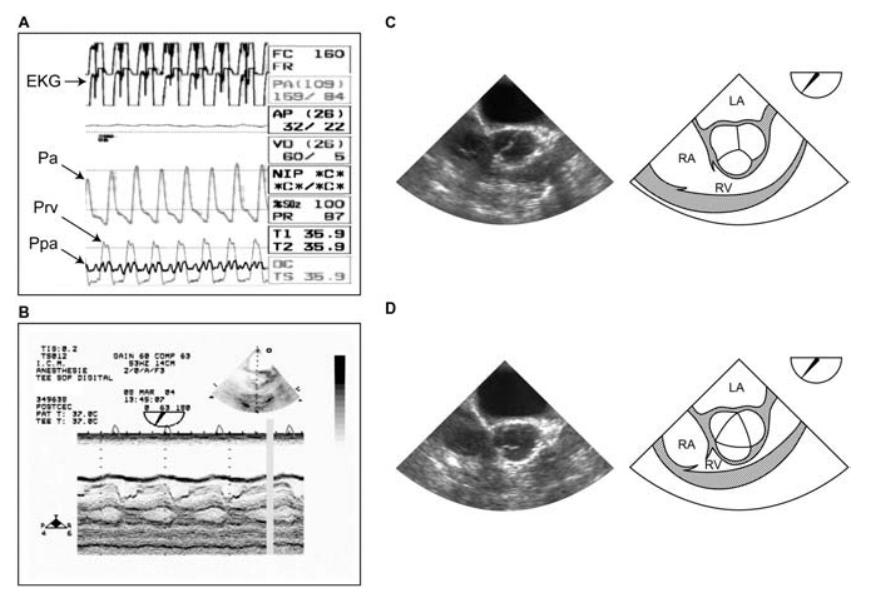

Figure 1. Septal myomectomy and aortic surgery in a 68-year-old man complicated by dynamic RVOT obstruction appearing during weaning from cardiopulmonary bypass. (A)The systolic gradient between the right ventricle and the pulmonary artery was $28 \mathrm{~mm}$ Hg. $(B, C, D)$ An M-mode view from a mid-oesophageal rightventricular inflow-outflow view at $63^{\circ}$ is illustrated with the systolic dynamic obstruction of the right ventricular outflow (LA, left atrium; $\mathrm{Pa}$, arterial pressure; $\mathrm{Ppa}$, pulmonary artery pressure; Prv, right ventricular pressure; RA, right atrium; RV, right ventricle).

pressure $<80 \mathrm{~mm} \mathrm{Hg}$, confirmed by central measurement (femoral or aortic), diastolic pulmonary artery pressure or pulmonary artery capillary wedge pressure $>15 \mathrm{~mm} \mathrm{Hg}$, and inotropic or vasopressive support for more than 1 hour (norepinephrine $>4 \mu \mathrm{g} / \mathrm{min}$, epinephrine $>2 \mu \mathrm{g} / \mathrm{min}$, dobutamine $>2 \mu \mathrm{g} / \mathrm{kg} \mathrm{min}^{-1}$ ) or the use of milrinone, mechanical support or intra-aortic balloon pump $(\text { IABP })^{1,20,21}$ to wean from CPB until transfer to the intensive care unit. All echocardiographic recordings were stored on magnetic optical disk and the examination findings stored in the database. The hemodynamic tracings were recorded on videotape. Finally to determine the precise incidence of RVOT obstruction, in the prospective series, 130 patients operated from September 2004 to May 2005 were continuously monitored using the paceport of the pulmonary artery catheter from the beginning to the end of the procedure. Chi-square test was used to compare RVOT obstruction in patients with or without difficult separation from CPB. The data are reported as mean \pm standard deviation.

\section{Results}

From August 2002 to September 2004, a total of 8 out of 670 consecutive patients undergoing TEE were found to have a RVOT gradient $>25 \mathrm{~mm} \mathrm{Hg}$. Two patients had transient mechanical RVOT obstruction during off-pump bypass surgery and were excluded from the analysis. Patient characteristics are listed in Table 1 . The mean age was $60 \pm$ 11 years, the mean duration of CPB was $168 \pm 97$ minutes and the average peak gradient was $31 \pm 4 \mathrm{~mm} \mathrm{Hg}$ (range 26 to $35 \mathrm{~mm} \mathrm{Hg}$ ). In all these 6 patients (1\%), RVOT obstruc- 
TABLE 2. Prospective series

\begin{tabular}{|c|c|c|c|c|c|c|c|c|c|c|}
\hline & Age & Sex & Procedure & $\begin{array}{c}\text { Predisposing } \\
\text { factor }\end{array}$ & HTN & PHT & $\begin{array}{c}\text { CPB } \\
\text { duration } \\
\text { (min) }\end{array}$ & DSB & Details & Outcome \\
\hline 1 & 26 & $\mathrm{~F}$ & $\begin{array}{l}\text { AVR and aortic } \\
\text { pseudoaneurysm } \\
\text { repair }\end{array}$ & Inotropes & $\mathrm{N}$ & $\mathrm{N}$ & 138 & $Y$ & $\begin{array}{l}\text { Noradrenaline } 4 \mu \mathrm{g} / \mathrm{min} \text {, } \\
\text { vasopressine } 2 \mathrm{units} / \mathrm{h} \text {, } \\
\text { nitroglycerine } 0.14 \\
\mu \mathrm{g} / \mathrm{kg} / \mathrm{min} \text {, inhaled } \\
\text { milrinone } 5 \mathrm{mg}\end{array}$ & $\begin{array}{l}\text { Vasoactive support for } 40 \\
\text { hours, hospitalisation } \\
21 \text { days }\end{array}$ \\
\hline 2 & 61 & $\mathrm{M}$ & $\begin{array}{l}\text { Coronary } \\
\text { revascularization }\end{array}$ & None & $Y$ & $\mathrm{~N}$ & 69 & No & $\begin{array}{l}\text { Noradrenaline } 2.5 \mu \mathrm{g} / \mathrm{kg} / \\
\text { min, vasopressine } 3 \\
\text { units bolus }\end{array}$ & $\begin{array}{l}\text { Vasoactive support } 3 \\
\text { hours, hospitalisation } 5 \\
\text { days }\end{array}$ \\
\hline 3 & 24 & $\mathrm{M}$ & $\begin{array}{l}\text { Repeated aortic } \\
\quad \text { surgery (Cabrol) }\end{array}$ & Inotropes & $\mathrm{N}$ & $\mathrm{N}$ & 208 & $Y$ & $\begin{array}{l}\text { Noradrenaline } 9 \mathrm{ug} / \mathrm{min} \text {, } \\
\text { nitroglycerine } 0.3 \mu \mathrm{g} / \\
\mathrm{kg} / \mathrm{min} \text {, vasopressine } \\
\text { bolus } 2 \text { units, calcium } \\
\text { chloride } 1 \mathrm{gm}\end{array}$ & $\begin{array}{l}\text { Vasoactive support for } 20 \\
\text { hours, death from } \\
\text { severe heart failure } \\
\text { from myocardial } \\
\text { infarction } 6 \text { days later } \\
\text { despite left ventricular } \\
\text { assist device }\end{array}$ \\
\hline 4 & 46 & $\mathrm{M}$ & $\begin{array}{l}\text { Heart } \\
\text { transplantation }\end{array}$ & Inotropes & $\mathrm{N}$ & $Y$ & 121 & $Y$ & $\begin{array}{l}\text { Noradrenaline } 25 \mu \mathrm{g} / \\
\text { min, nitroglycerine } 0.7 \\
\mu \mathrm{g} / \mathrm{kg} / \mathrm{min} \text {, milrinone } \\
50 \mu \mathrm{g} / \mathrm{kg} \text {, inhaled } \\
\text { prostacyclin } 60 \mu \mathrm{g}, \\
\text { adrenalin } 2 \mu \mathrm{g} / \mathrm{min}, \\
\text { vasopressine } 2 \text { units/ } \\
\text { hour, isoproterenol } 3 \\
\mu \mathrm{g} / \mathrm{min}\end{array}$ & $\begin{array}{l}\text { Vasoactive support for } 27 \\
\text { days, hospitalisation } \\
119 \text { days }\end{array}$ \\
\hline 5 & 68 & $\mathrm{M}$ & AVR & $\begin{array}{l}\text { LVH, } \\
\text { inotropes }\end{array}$ & $Y$ & $\mathrm{~N}$ & 168 & $Y$ & $\begin{array}{l}\text { Noradrenaline } 30 \mu \mathrm{g} / \\
\text { min, nitroglycerine } 0.2 \\
\mu \mathrm{g} / \mathrm{kg} / \mathrm{min} \text {, inhaled } \\
\text { milrinone } 5 \mathrm{mg} \text {, } \\
\text { ephedrine } 5 \mathrm{mg} \text {, } \\
\text { vasopressine } 1 \text { unit } \\
\text { bolus }\end{array}$ & $\begin{array}{l}\text { Had unexplained } \\
\text { hypotension requiring } \\
\text { vasoactive support for } \\
3 \text { days, hospitalisation } \\
9 \text { days }\end{array}$ \\
\hline
\end{tabular}

$A V R$, aortic valve replacement; $C P B$, cardiopulmonary bypass; $D S B$, difficult separation from CPB; $H T N$, hypertension; $L V H$, left ventricular hypertrophy; min, minutes; $P H T$, pulmonary hypertension.

TABLE 3. Hemodynamic conditions during RVOT obstruction

\begin{tabular}{|c|c|c|c|c|c|c|}
\hline Retrospective series & HR (beats/min) & $\mathrm{Pa}(\mathrm{mm} \mathrm{Hg})$ & Ppa $(\mathrm{mm} \mathrm{Hg})$ & Systolic Prv (mm Hg) & RVOT Gradient (mm Hg) & Pra $(\mathrm{mm} \mathrm{Hg})$ \\
\hline Patient 2 & 95 & $118 / 42(59)$ & $21 / 11(15)$ & 47 & 26 & 11 \\
\hline Patient 4 & 71 & $85 / 55(65)$ & $55 / 27(38)$ & 90 & 35 & 15 \\
\hline Patient 5 & 80 paced & $159 / 84(109)$ & $32 / 22(26)$ & 60 & 28 & 6 \\
\hline Patient 6 & 125 & $116 / 48(70)$ & $18 / 11(14)$ & 48 & 30 & 8 \\
\hline Patient 2 & 90 & $123 / 57(79)$ & $27 / 14(20)$ & 54 & 27 & 12 \\
\hline Patient 3 & 100 & $112 / 40(55)$ & $18 / 11(15)$ & 62 & 44 & 8 \\
\hline Patient 4 & 94 & $117 / 69(86)$ & $39 / 21(28)$ & 67 & 28 & 8 \\
\hline Patient 5 & 103 & $123 / 51(70)$ & $18 / 9(14)$ & 78 & 60 & 4 \\
\hline
\end{tabular}

RVOT, right ventricular outflow tract; $H R$, heart rate; $P a$, arterial pressure; $P p a$, pulmonary artery pressure; Prv, right ventricular pressure; $P r a$, right atrial pressure. 

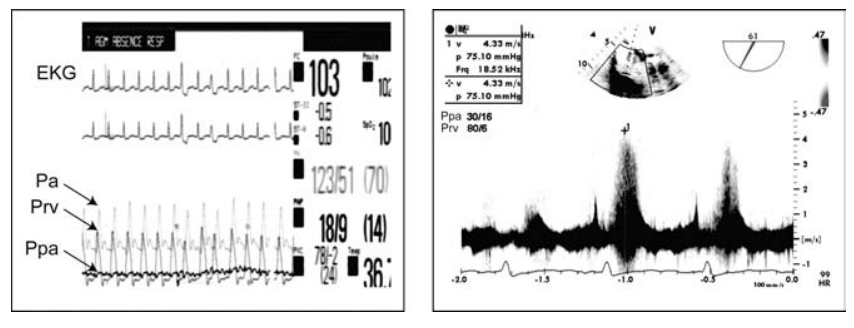

Figure 2. A 68-year-old man underwent aortic valve replacement. He became hemodynamically unstable with right ventricular dysfunction and went back on cardiopulmonary bypass. Inotropes were started. On the second weaning attempt, he developed severe right ventricular outflow tract obstruction confirmed with the paceport of the pulmonary artery catheter and through continuous-wave Doppler interrogation of the tricuspid regurgitant flow in a mid-oesophageal right ventricular inflow-outflow view at $61^{\circ}$. The measured pressure gradient of the tricuspid regurgitant flow was $75 \mathrm{~mm} \mathrm{Hg}$ (with a right ventricular systolic pressure of $80 \mathrm{~mm} \mathrm{Hg}$ ) and the pulmonary artery pressure (Ppa) was 30/16 $\mathrm{mm} \mathrm{Hg}$ during the echocardiographic measurement. (EKG, electrocardiogram; $\mathrm{Pa}$, arterial pressure; $\mathrm{Prv}$, right ventricular pressure).

tion occurred after CPB and was associated with systolic obliteration in the RVOT (Figure 1). In most of these patients, the gradient improved or normalized as the right ventricular preload was increased and the inotropic agents were decreased or discontinued.

In the prospective study (Table 2), a total of 6 patients out of 130 had significant RVOT obstruction. One patient had RVOT obstruction during ventricular mapping secondary to cardiac manipulation and was excluded. Five patients $(4 \%)$ were therefore found to have new-onset significant dynamic RVOT obstruction after CPB. The mean age of the patients was $45 \pm 20$ years, the mean duration of CPB was $141 \pm 52$ minutes and the average peak gradient was $37 \pm 15 \mathrm{~mm} \mathrm{Hg}$ (range 27 to $60 \mathrm{~mm}$ $\mathrm{Hg}$ ). The hemodynamic conditions of both groups of patients at the time that the RVOT obstruction was observed are described in Table 3. The average heart rate was $96 \pm 13$ beats/min, systolic, diastolic and mean systemic arterial pressures were $114 \pm 20,56 \pm 14$ and $75 \pm 15 \mathrm{~mm} \mathrm{Hg}$, systolic, diastolic and mean pulmonary artery diastolic pressures were $29 \pm 11,17 \pm 6$ and $21 \pm$ $7 \mathrm{~mm} \mathrm{Hg}$. The average systolic right ventricular and right atrial pressures were $63 \pm 13 \mathrm{~mm} \mathrm{Hg}$ and $11 \pm 5 \mathrm{~mm} \mathrm{Hg}$. The mean gradient was $34 \pm 10 \mathrm{~mm} \mathrm{Hg}$ (range 26 to 60 $\mathrm{mm} \mathrm{Hg}$ ). Difficult separation from CPB was observed in $41 \%$ of the 670 patients in the retrospective group, in $46 \%$ of the 130 patients of the prospective group and in $91 \%$ of patients with dynamic RVOT obstruction $(P=$ .0014). The drugs required for weaning from CPB, the duration of vasoactive support and the outcome are described in Table $1 \& 2$. In 3 patients in whom a Doppler tricuspid regurgitant jet could be measured, the pressure gradient estimated with the simplified Bernoulli equation was superior to the pulmonary artery pressure (Figure 2).

\section{Discussion}

The observed prevalence of significant dynamic RVOT obstruction in the study was $1 \%$ in the retrospective cohort, while it was $4 \%$ in the prospective cohort. In 10/11 patients (91\%) RVOT obstruction was associated with difficult separation from CPB from hemodynamic instability. The diagnostic criteria of RVOT obstruction and the associated echocardiographic findings observed in the study are summarized in Table 4.

Right ventricular outflow tract obstruction was documented in all patients through right ventricular pressure monitoring, with direct pressure measurements in the

\section{TABLE 4. Criteria for significant right ventricular outflow tract (RVOT) obstruction}

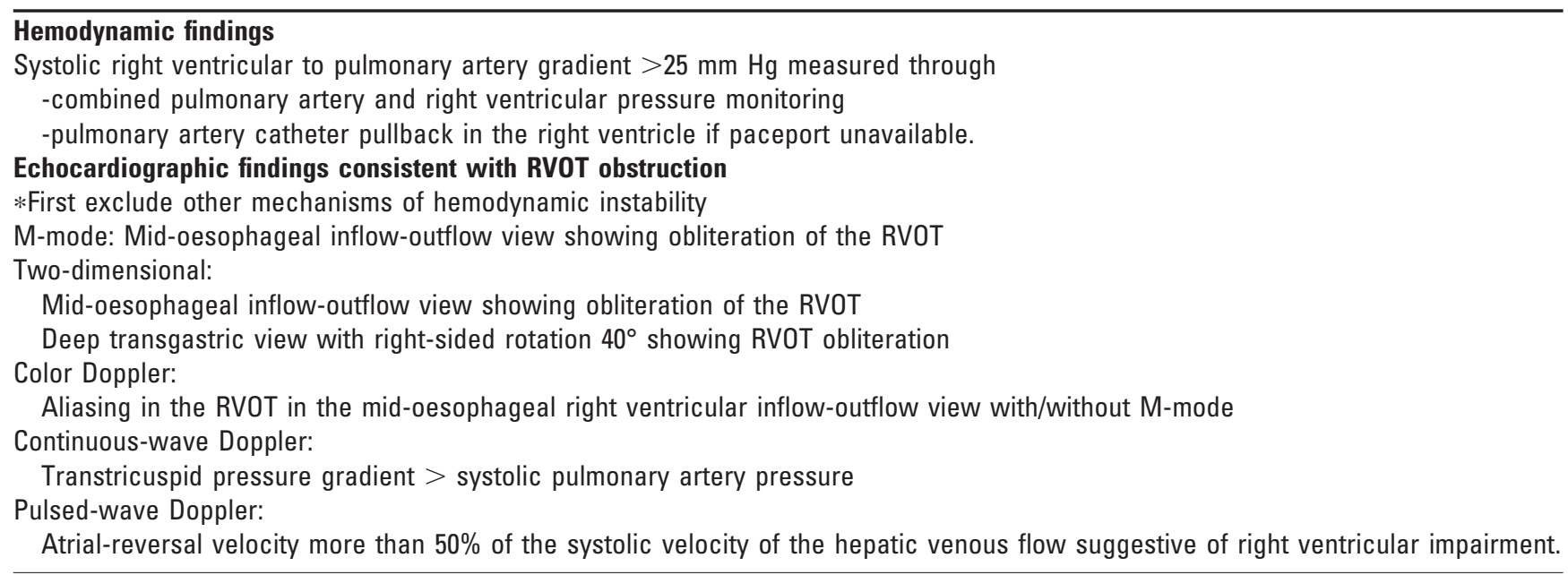


pulmonary artery and right ventricle. Systolic obliteration of the RVOT was seen with TEE in the mid-oesophageal right ventricular inflow-outflow tract view. Right ventricular systolic pressure derived from continuous Doppler interrogation of the tricuspid valve and central venous pressure also revealed that the right ventricular maximal systolic pressure was higher than the pulmonary artery systolic pressure.

\section{The Association Between RVOT Obstruction and Hemodynamic Instability}

Extrinsic RVOT obstruction has been recognized as a possible cause of hemodynamic instability ${ }^{17}$ after cardiac surgery. Extrinsic compression can occur from an aortic ${ }^{2}$ or pulmonary artery aneurysm, ${ }^{3}$ mediastinal hematoma ${ }^{4}$ or direct surgical compression during off-pump surgery. In contrast, intrinsic obstruction has been described with congenital heart disease, ${ }^{5,6-7}$ hypertrophic cardiomyopathy ${ }^{9}$ and after lung transplantation. ${ }^{10,11}$

New onset dynamic subvalvular RVOT obstruction, as was observed in this study, usually occurs in the setting of reduced preload, hypertrophied right ventricle and in patients on inotropic therapy. ${ }^{10}$ In our series inotropic agents and left ventricular hypertrophy were present in 10 patients (91\%). The occurrence of dynamic RVOT obstruction in a patient on inotropic therapy could contribute to hemodynamic instability. This conclusion is based on the fact that further deterioration of the hemodynamic status of the patients in the study was often associated with the development of significant RVOT obstruction. In this circumstance, optimisation of right ventricular preload instead of increasing inotropic therapy, improved the clinical status of the patients.

Although uncommon, the presence of significant dynamic RVOT obstruction should be suspected in any hemodynamically unstable patients receiving inotropes. In our patients, none had a significant right ventricular to pulmonary artery systolic gradient before CPB and inotropes were used only after CPB for weaning. The average CPB time was more than 2 hours which increases the risk of cardiac function impairment and may explain why the anesthesiologist considered using inotropic agents. These agents were stopped once the diagnosis of RVOT obstruction was made. The administration of inotropic agents may have promoted RVOT obstruction in our study. It should be emphasized that significant RVOT obstruction can also occur without any preoperative risk factor as we observed in one patient. In the operating room, continuous right ventricular pressure monitoring through the pacemaker port represents an easier method to rapidly diagnose RVOT obstruction compared to pulling back the pulmonary artery catheter in the right ventricle. In the latter situation, ventricular arrhythmias can occur, which we did not observe using the paceport catheter as a continuous pressure monitor.
Pathophysiologically, dynamic RVOT obstruction can be explained by the increased susceptibility of the infundibulum to inotropic agents. In fact, the inotropic response of the infundibulum is greater than that of the inflow tract, perhaps as a mechanism to protect the pulmonary vasculature from high pressure. ${ }^{22,23}$ This differential response could explain the presence of dynamic RVOT obstruction in patients on inotropes or during cardiac surgery. Moreover, the coordinated sequence of activation of the right ventricle can also be reversed by the post-operative hyperadrenergic states. ${ }^{24}$ In normal conditions, right ventricular contraction is sequential starting with the contraction of the trabeculated myocardium and ending with that of the infundibulum (approximately 25 to 50 milliseconds later). In the presence of sympathetic stimulation or norepinephrine infusion the normal sequence of activation may be abolished and RV inflow contraction can even occur after infundibular contraction.

There are several limitations from this case series. The diagnosis of RVOT obstruction was unexpected and most of the time was associated with hemodynamic instability. Therefore we did not have the opportunity to obtain a detailed hemodynamic profile. This is why we only reported the maximal gradient that occurred at that time. The number of patients is also too small to make generalisation about the best therapeutic approach but in all our patients, except the one undergoing heart transplantation, the inotropes were stopped and avoided in the post-operative period. However, the interest of our findings lies at this point in the knowledge of this entity when faced with patients with hemodynamic instability after CPB and the potential correct therapy.

In summary, dynamic RVOT obstruction can occur in several types of cardiac surgery. The diagnosis is easily obtained with continuous right ventricular and pulmonary artery pressure monitoring, and can also be suspected with TEE. In cardiac surgical patients experiencing hemodynamic instability, dynamic RVOT obstruction should be considered especially when TEE reveals right ventricular cavity obliteration or turbulent flow patterns. The presence of dynamic RVOT obstruction can contribute to hemodynamic instability, and in that situation inotropic agents could be responsible for or could exacerbate this condition. In our experience, preload optimization and inotropic agents withdrawal were successful in the management of this condition.

\section{References}

1. Costachescu T, Denault AY, Guimond JG, Couture P, Carignan S, Sheridan P, Hellou G, Blair L, Normandin L, Babin D, Allard M, Harel $\mathrm{F}$, Buithieu J. The hemodynamically unstable patient in the intensive care unit: hemodynamic vs. transesophageal echocardiographic monitoring. Crit Care Med. 2002;30:1214-23.

2. Doshi SN, Kim MC, Sharma SK, Fuster V. Images in cardiovascular medicine. Right and left ventricular outflow tract obstruction in hypertrophic cardiomyopathy. Circulation. 2002;106:e3-e4. 
3. Agarwal S, Choudhary S, Saxena A, Ray R, Airan B. Giant pulmonary artery aneurysm with right ventricular outflow tract obstruction. Indian Heart J. 2002;54:77-9.

4. Tardif JC, Taylor K, Pandian NG, Schwartz S, Rastegar H. Right ventricular outflow tract and pulmonary artery obstruction by postoperative mediastinal hematoma: delineation by multiplane transesophageal echocardiography. J Am Soc Echocardiogr. 1994;7:400-4.

5. Dall'Agata A, Cromme-Dijkhuis AH, Meijboom FJ, Spitaels SE, McGhie JS, Roelandt JR, Bogers AJ. Use of three-dimensional echocardiography for analysis of outflow obstruction in congenital heart disease. Am J Cardiol. 1999;83:921-5.

6. Bennink GB, Hitchcock FJ, Molenschot M, Hutter P, Sreeram N. Aneurysmal pericardial patch producing right ventricular inflow obstruction. Ann Thorac Surg. 2001;71:1346-7.

7. Basaria S, Denktas AE, Ghani M, Thandroyen F. Ventricular septal defect patch causing right ventricular inflow tract obstruction. Circulation. 1999;100:e12-e13.

8. Therrien J, Dore A, Gersony W, Iserin L, Liberthson R, Meijboom F, Colman JM, Oechslin E, Taylor D, Perloff J, Somerville J, Webb GD. CCS Consensus Conference 2001 update: recommendations for the management of adults with congenital heart disease. Part I. Can J Cardiol. 2001;17:940-59.

9. Stierle U, Sheikhzadeh A, Shakibi JG, Langbehn AF, Diederich KW. Right ventricular obstruction in various types of hypertrophic cardiomyopathy. Jpn Heart J. 1987;28:115-25.

10. Kirshbom PM, Tapson VF, Harrison JK, Davis RD, Gaynor JW. Delayed right heart failure following lung transplantation. Chest. 1996; 109:575-7.

11. Gorcsan J, III, Reddy SC, Armitage JM, Griffith BP. Acquired right ventricular outflow tract obstruction after lung transplantation: diagnosis by transesophageal echocardiography. J Am Soc Echocardiogr. 1993;6:324-6

12. Werner AM, Darrell JC, Pallegrini RV, Woelfel GF, Grant K, Marrangoni AG. Right ventricular outflow obstruction with intact ventricular septum in adults. Tex Heart Inst J. 1997;24:105-8.

13. Gomez CM, Palazzo MG. Pulmonary artery catheterization in anaesthesia and intensive care. Br J Anaesth. 1998;81:945-56.

14. Shanewise JS, Cheung AT, Aronson S, Stewart WJ, Weiss RL, Mark JB, Savage RM, Sears-Rogan P, Mathew JP, Quinones MA, Cahalan
MK, Savino JS. ASE/SCA guidelines for performing a comprehensive intraoperative multiplane transesophageal echocardiography examination: recommendations of the American Society of Echocardiography Council for Intraoperative Echocardiography and the Society of Cardiovascular Anesthesiologists Task Force for Certification in Perioperative Transesophageal Echocardiography. Anesth Analg. 1999;89:870-84.

15. Khouri SJ, Maly GT, Suh DD, Walsh TE. A practical approach to the echocardiographic evaluation of diastolic function. J Am Soc Echocardiogr. 2004;17:290-7.

16. Ge Z, Zhang Y, Kang W, Fan D, Ji X, Duran C. Noninvasive evaluation of right ventricular and pulmonary artery systolic pressures in patients with ventricular septal defects: simultaneous study of Doppler and catheterization data. Am Heart J. 1993;125:1073-81.

17. Denault AY, Ferraro P, Couture P, Boudreault D, Babin D, Poirier C, Buithieu J. Transesophageal echocardiography monitoring in the intensive care department: the management of hemodynamic instability secondary to thoracic tamponade after single lung transplantation. $J$ Am Soc Echocardiogr. 2003;16:688-92.

18. Moraes D, Loscalzo J. Pulmonary hypertension: newer concepts in diagnosis and management. Clin Cardiol. 1997;20:676-82.

19. Levy D, Labib SB, Anderson KM, Christiansen JC, Kannel WB, Castelli WP. Determinants of sensitivity and specificity of electrocardiographic criteria for left ventricular hypertrophy. Circulation. 1990; 81:815-20.

20. Bernard F, Denault AY, Babin D, Goyer C, Couture P, Couturier A, Buithieu J. Diastolic dysfunction is predictive of difficult weaning from cardiopulmonary bypass. Anesth Analg. 2001;92:291-8.

21. Hardy JF, Searle N, Roy M, Perrault J. Amrinone, in combination with norepinephrine, is an effective first-line drug for difficult separation from cardiopulmonary bypass. Can J Anaesth. 1993;40:495-501.

22. Heerdt PM, Pleimann BE. The dose-dependent effects of halothane on right ventricular contraction pattern and regional inotropy in swine. Anesth Analg. 1996;82:1152-8.

23. Stobierska-Dzierzek B, Awad H, Michler RE. The evolving management of acute right-sided heart failure in cardiac transplant recipients. J Am Coll Cardiol. 2001;38:923-31.

24. Dell'Italia LJ. The right ventricle: anatomy, physiology, and clinical importance. Curr Probl Cardiol. 1991;16:653-720. 